\title{
Analysis of China's Short-term Capital Flow Based on the Errors and Omissions Account
}

\author{
Xiaojing Zhang \\ School of Finance, Harbin University of Commerce, China \\ book97@163.com
}

Keywords: Short-term capital; Flow; The errors and omissions; Exchange rate; GDP

\begin{abstract}
In order to judge the causes of China's short-term capital flow, this paper analyzes the fluctuating trend of the errors and omissions account. It is found that the errors and omissions account is an important indicator to monitor capital flow, especially the short-term capital, and its fluctuating trend is relatively weak associated with that of $R M B$ rate, on the contrary it is strongly associated with that of GDP growth rate which implies that capital inflow or capital flight is also strongly associated with that of GDP growth rate. As a result, the economic fundamental is the important factor to decide capital inflow or flight on a large scale.
\end{abstract}

\section{Introduction}

The errors and omissions account in BOP, which is added artificially to achieve the book equilibrium, is not paid attention as much as the current or capital account. In a general way, it mainly includes the statistic errors and capital flight. The errors and omissions account is always treated as a leading indicator when scholars in the world estimate the scale of capital flight in an economy using the direct approach[1-6]. With the sustaining economic growth, China's current and capital account have been maintaining surplus for many years since the reform and opening. "Double surplus" brought China enormous foreign exchange reserves day by day, which solved the problem of foreign exchange gaps in the early stages of economic takeoff and built a firm foundation for $R M B$ internationalization by promoting the status of $R M B$ in the international financial system. However, "double surplus" had also negative influences. For example, it causes a great number of foreign arbitrage capital inflow, raised the assets prices and increased the financial risks under the background of $R M B$ appreciation year in year out. Moreover, the passive mirror image of foreign exchange reserve with mandatory system of foreign exchange settlement and sale brought China inflation pressure. In recent years, with some FDI enterprises moved to South and East Asia due to China's "Step Out" strategy and factor prices rising, China's BOP is showing a more reasonable structure of the current account surplus and the capital account deficit. What is worth noticing is that China's foreign exchange reserves have been declining for five months over the period of April to September in 2015, especially declined for 93.929 billion dollars in August, see Table 1. Then it causes great attention among the academic circles, the media and the market agents[7-11]. And now, whether it means a lot of capital flight or not?

Table 1 China's foreign exchange reserves during April to September in 2015

hundred millions of dollars

\begin{tabular}{|c|c|c|c|c|c|c|}
\hline Month/Year & $04 / 2015$ & $05 / 2015$ & $06 / 2015$ & $07 / 2015$ & $08 / 2015$ & $09 / 2015$ \\
\hline $\begin{array}{c}\text { Foreign exchange } \\
\text { reserves }\end{array}$ & 37481.42 & 37111.43 & 36938.38 & 36513.10 & 35573.81 & 35141.20 \\
\hline
\end{tabular}

Source: People's Bank of China

http://www.pbc.gov.cn/diaochatongjisi/resource/cms/2015/08/2015081417592419609.htm 


\section{Analysis of the Errors and Omissions Account}

This paper will study the problem above based on the fluctuating trend of the errors and omissions account.

The data of the errors and omissions account in 1994 for research is used to be the starting point since the first exchange rates reform occurred in the year. The data of 21 years from 1994 to 2014 is shown in Table 2, and the fluctuating trend of the errors and omissions account is shown in Fig. 1.

Table 2 The data of China's errors and omissions account during 1994-2014 hundred millions of dollars

\begin{tabular}{|c|c|}
\hline Year & Errors and omissions \\
\hline 1994 & -97.75 \\
\hline 1995 & -178.30 \\
\hline 1996 & -155.47 \\
\hline 1997 & -222.55 \\
\hline 1998 & -187.24 \\
\hline 1999 & -177.88 \\
\hline 2000 & -118.93 \\
\hline 2001 & -48.56 \\
\hline 2002 & 77.94 \\
\hline 2003 & 82.24 \\
\hline 2004 & 129.67 \\
\hline 2005 & 229.21 \\
\hline 2006 & 36.281 \\
\hline 2007 & 132.90 \\
\hline 2008 & 188.44 \\
\hline 2009 & -413.83 \\
\hline 2010 & -529.36 \\
\hline 2011 & -137.66 \\
\hline 2012 & -870.74 \\
\hline 2013 & -629.25 \\
\hline 2014 & -1401.37 \\
\hline
\end{tabular}

Source: State Administration of Foreign Exchange. http://www.safe.gov.cn/

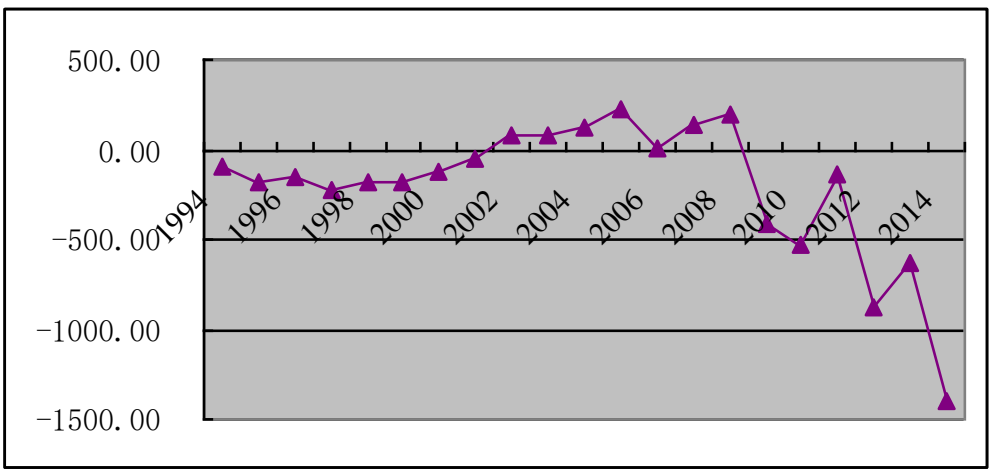

Figure 1. The fluctuating trend of China's errors and omissions account during 1994-2014

It can be found in Table 2 that China's errors and omissions account were all deficit during 1994-2001. To a great extent, we can judge that it indicates continuous capital fight from China 
during the period with the exception of statistic errors. Suppose that the proportion of statistic errors in the errors and omissions account is $\Psi(0<\Psi<1)$ and its value is invariable, then the proportion of capital flight is $1-\Psi$. In 1994 China debased the value of $R M B$ for fifty percent at one time while carrying out the first exchange rate reform that $R M B$ official rate and swap centers rate merged, beginning to put through single and controlled floating rate system based on market supply and demand, at that time the rate of $R M B$ against US dollar depreciated to 8.62 in 1994 from the mean 5.76 in 1993(direct foreign exchange quotation). Under the background, the agents intensively expected $R M B$ rate would depreciate more and then the scale of capital flight expanded to 17.83(1$\Psi)$ billions of dollars in 1995 from 9.78(1- $\Psi$ ) billions of dollars in 1994, and it reached to a peak of $22.25(1-\Psi)$ billions of dollars during the South and East financial crisis in 1997. It narrowed constantly in the following years and declined to $4.86(1-\Psi)$ billions of dollars in 2001. On the contrary, the rate of $R M B$ against US dollar continuously appreciated to 8.28 in 2001 from 8.62 in 1994 during the same period, it showed that the capital flow direction and the fluctuating trend of exchange rate was opposites. However, China's GDP growth rate continuously declined to $8.30 \%$ in 2001 from $13.08 \%$ in 1994 over the same period. Prima facie, the capital flow direction was relatively accordant with the fluctuating trend of GDP growth rate.

With China joining WTO on 11th of December in 2001, a number of trade barriers in the US and Europe were lifted, then China's foreign trade developed rapidly and injected powerful strength for economic growth. Moreover, China took active fiscal measure after South and East financial crisis in 1997, thus China's economy went to a sustaining and rapid growth period that GDP growth rate breached the former juncture $8 \%$ and reached $9.08 \%$. After that, it rose all the way and breached the junctures of $9 \%, 10 \%, 11 \%$ and $12 \%$ at short intervals, then it reached the striking $14.16 \%$. Under the background of sustaining and rapid economic growth, China's errors and omissions account of BOP had been positive over the period of 2002-2008, which indicates that the capital were net inflow, while the exchange rate of $R M B$ against US dollar had been relatively stable during 2002-2004 and maintained the level of about 8.27. However, the capital net inflow based on errors and omissions account didn't swag synchronously when $R M B$ rate began to appreciate sharply every year which rose to 6.84 in 2008 from 8.28 in 2004 since the second exchange rate reform. By contrast, it fell sharply to $3.63(1-\Psi)$ billions of dollars in 2006 from $22.92(1-\Psi)$ billions of dollars in 2005 and just got over $10(1-\Psi)$ billions of dollars again in 2007, 2008, yet it was not in excess of $20(1-\Psi)$ billions of dollars.

China's errors and omissions account were all deficit during 2009-2014. To a great extent, we can judge that it indicates continuous capital fight from China during the period with the exception of statistic errors and the scale of capital fight soared to $140.14(1-\Psi)$ billions of dollars in 2014 from $41.4(1-\Psi)$ billions of dollars in 2009. Over the period, the direction of capital flow was in contrast with the fluctuating trend of $R M B$ rate although the exchange rate of $R M B$ against US dollar had been appreciating continuously which rose to 6.12 in 2014 from 6.83 in 2009 . At the same time, China's GDP growth rate had been declining which fell to $7.40 \%$ in 2014 from $9.21 \%$ in 2009. Again, the capital flow direction was relatively accordant with the fluctuating trend of GDP growth rate.

It can be found clearly that China's errors and omissions account of BOP fluctuated in accordance with the GDP growth rate over the period of 1994-2014 if they are incorporated in the same analysis framework, see Fig. 2. ${ }^{2}$

The data of GDP growth rate are processed which multiply 10,000 separately and then get the graphics since the balance of absolute value of GDP growth rate and the error and omission account is so large that it is difficult to analyze them on graphics. 


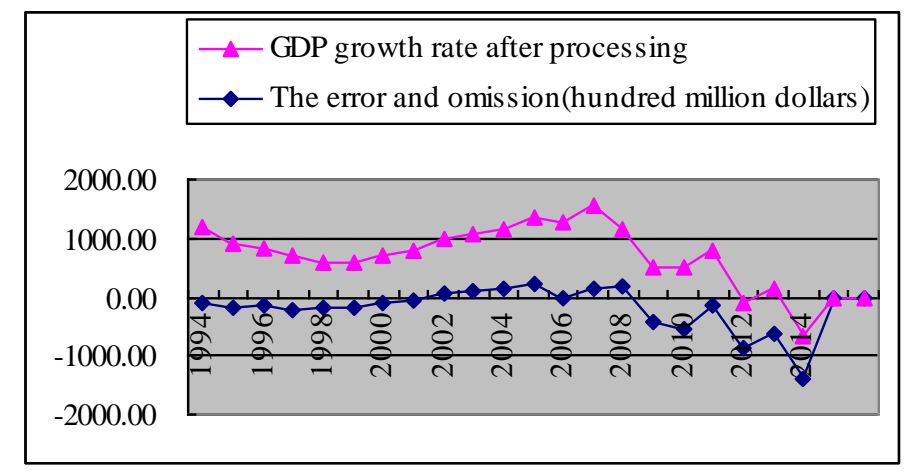

Figure 2. The fluctuating trend of errors and omissions account and GDP growth rate during 1994-2014

\section{Conclusions}

What conclusion we can draw is that the errors and omissions account is an important indicator to monitor capital flow, especially the short-term capital. On the basis of the analysis above, it can be found that the fluctuating trend of errors and omissions account is relatively weak associated with that of $R M B$ rate, and it is strongly associated with that of GDP growth rate which implies that capital inflow or capital flight is also strongly associated with that of GDP growth rate. As a result, the economic fundamental is the important factor to decide capital inflow or flight on a large scale.

In order to prevent capital inflow and outflow on a large scale which will threat China's financial safety and steady, China should not only promote economic growth reposefully for the moment, but also treat the capital account opening prudently in the process of $R M B$ internationalization, especially need to crack down on the illegal private banks and arbitrage capital mixing with trade account further.

\section{Acknowledgements}

Supported by the PhD Research Fund in Harbin University of Commerce(15RW18).

\section{References}

[1] J T Cuddington. Capital Flight: Estimates, Issues, and Explanations [J]. Princeton Studies in International Finance, 1986, 12.

[2] C Kant. Foreign Direct Investment and Capital Flight [J]. Princeton Studies in International Finance, 1996, 3.

[3] Friedrich Wu, Leslie Tang. China's Capital Flight, 1990-1999: Estimates and Implications [J]. Review of Pacific Basin Financial Markets \& Policies, 2011, 3.

[4] Yuming Yin, Haibo Tao. Hot Money: Scale and Effect [J]. Finance and Economics Science, 2005(6): pp 131-137.

[5] Liya Liu. If hot Money Stimulate the Stock Market and Real Estate market rising? [J]. Journal of Financial Research, 2008(10): pp 48-70.

[6] Ming Zhang. The International Short-term Capital flow Faced Up to China [J]. World Economy, 2011(2): pp 39-56.

[7] Wenxin Niu. The Factors of RMB Devaluation Are Increasing[J]. CEWEEKLY, 2015(5):17-17.

[8] Liuhan Yang. RMB devaluation and capital flight[J]. Financial Market Research, 2015, 34(3): 95-98. 
[9] Fan Yin, Lu liu. China's Economy Will Face a Severe Test of Capital Flight[J]. China's Foreign Investment Monthly, 2014(2): pp 227-227.

[10]Jie Zeng. Analysis of the Causes of China's Foreign Exchange Reserves Decrease[J]. Market Modernazation, 2015(22): pp 166-166.

[11]Xianrong Yi. Will the Expectation of RMB Devaluation Be Really Reversed?[J]. Shanghai Enterprises, 2015, 10: pp 64-64. 